\title{
CAPTAÇõES DE ÁGUA SUBTERRÂNEA NO CAMPUS DA UFSM, SANTA MARIA - RS
}

\author{
José Luiz Silverio da Silva ${ }^{1}$, Quelen da Silva Osorio², Celina Dutra Moreira, \\ Carlos Alberto Löbler \\ 1 silverioufsm@gmail.com, ${ }^{2}$ http://www.bomjesus.br
}

\section{RESUMO}

Atualmente há um aumento significativo do uso das águas subterrâneas, devido ao menor custo de tratamento, distribuição e, principalmente, escassez de recursos hídricos. Desde 1960 já foram perfurados mais 50 poços tubulares para abastecer cerca de 17.000 pessoas, que circulam no Campus da Universidade Federal de Santa Maria/UFSM, no Estado do Rio Grande do Sul. Até 2006, 20 captações supriam um consumo médio de $850 \mathrm{~m}^{3} /$ dia. Esse abastecimento era realizado totalmente por poços tubulares sendo as águas subterrâneas explotadas do Sistema Aquífero Guarani/SAG, na borda da Bacia do Paraná. O objetivo da pesquisa foi investigar a situação atual das captações e disponibilidade das águas subterrâneas, através da preparação de um banco de dados incluindo a análise da condição de funcionamento dos poços e parâmetros hidrodinâmicos buscando subsidiar a gestão racional. Constatou-se que as águas estão de acordo com as normas estabelecidas para consumo humano. Ainda não há um bom controle dos níveis piezométricos. Notou-se uma variação dos níveis estáticos dos poços, provavelmente oriundos do aumento do consumo de água na construção de novos prédios e/ou relativos às alterações climáticas. Apresenta-se um balanço hídrico climático avaliado num curto período de cinco anos. $O$ sistema aquífero explotado é raso com poços penetrando entre $47 \mathrm{~m}$ a $128 \mathrm{~m}$ de profundidade águas doces.

Palavras chave: aquífero, poços tubulares, SAG, gestão.

\section{ABSTRACT}

Currently there is a significant increase in the use of groundwater due to lower processing cost, distribution, and especially water shortages. Since 1960 have been drilled over 50 tubular wells to supply about 17.000 people, which circulate in the Federal University of Santa Maria Campus, Rio Grande do Sul state, southern Brazil. However, circa the 20 tubular wells were active until 2006 to meet one average consumption of $850 \mathrm{~m}^{3} /$ day. This was done entirely by wells being exploited Guarani Aquifer System/GAS, Paraná Basin. The aim was to investigate the situation and availability of the fresh groundwaters, through preparation of a database, analysis the operation condition of the wells to provide technical information for the grant. It was found that the waters are in accordance with guidelines for human consumption. It was also noted that there is not a good control of the piezometric levels and there was a variation of the static levels of the wells, probable assocition with the increase in the water consumption, new buildings and/or on climate change which alter the ability of the recharge. Presents one climatic water balance for one short period by five years. The aquifer system is exploited with shallow wells ranging from $47 \mathrm{~m}$ to $128 \mathrm{~m}$ deep with fresh water.

Key-words: aquifer, tubular wells, GAS, managment. 


\section{INTRODUÇÃO}

Atualmente vivencia-se uma realidade em que a quantidade e a qualidade dos recursos naturais que sustentam a nossa vida estão ameaçados, como prova há existência de escassez da água em vários países. Segundo o Secretário Geral da ONU, "se o desperdício atual continuar, em vinte anos, duas pessoas em cada três sofrerão efeitos da escassez da água" (Freitas et al., 2004).

Rebouças (1992) já dizia que "dentro da moderna abordagem do gerenciamento integrado dos recursos hídricos, as águas subterrâneas representam a parcela do ciclo hidrológico que transita pelo subsolo de um sistema hidrográfico. Estas águas ocorrem nos microporos, fraturas, fissuras das rochas. Os aquíferos correspondem aos corpos rochosos que apresentam, relativamente, as melhores características de porosidade (estocagem) e de permeabilidade (fluxo). As rochas sedimentares clásticas, em geral com porosidade primária intergranular, constituem os melhores aquíferos. Quando afloram na superfície topográfica constituem aquíferos livres e, neste caso, apresentam acentuadas interações com os corpos de água de superfície (rios, lagos naturais ou artificiais) e, com as formas de uso e ocupação do meio físico".

O Campus da Universidade Federal de Santa Maria/UFSM, localizado a $11 \mathrm{~km}$ da área urbana do município homônimo. Teve sua fundação no final do ano de 1960 numa área rural. Desde então o abastecimento de água para diversos fins: humano, animal, irrigação/ jardinagem, lazer, industrial (múltiplo) vem sendo realizado através de captações por poços tubulares. 0 Hospital Universitário que atende uma ampla parcela de municípios do estado é o maior consumidor. Desta forma cada novo prédio construído era contemplado com uma captação subterrânea através de poços tubulares. Algumas captações foram executadas, mesmo antes, da aprovação das normas técnicas ABNT/NBR 12.212/1992 e 12.244/1992 atualizadas em 2006. No ano de 2008 foi solicitada ao Departamento de Recursos Hídricos da Secretaria de Meio Ambiente/SEMA/RS a outorga de direito de uso das águas subterrâneas, de acordo com o Decreto Estadual № 42.047/2002 que trata do gerenciamento e da conservação das águas subterrâneas e dos aquíferos no Estado do Rio Grande do Sul.

Uma vez que as águas subterrâneas apresentam, normalmente, uma qualidade natural que Ihes fornece potabilidade, seus usos devem seguir as normas preconizadas pela Organização Mundial da Saúde/OMS, a Resolução CONAMA №396/2008, e Portaria MS №2914/2011.

Assim, é indispensável um estudo minucioso dos aquíferos que revelem a situação qualitativa e quantitativa das águas, para que sua exploração seja executada de forma racional. Deste modo, as áreas de recarga e descarga devem ser conhecidas para evitarem-se atividades que se tornem possíveis fontes potenciais de poluição e/ou alteração na qualidade natural das águas subterrâneas.

Atenção especial vem sendo dada à qualidade da água em nível mundial, fato que se faz presente entre a comunidade do Campus da UFSM, que se preocupa com quantidade e a qualidade da água consumida através da parceria entre diferentes setores da instituição. $O$ abastecimento de água no Campus proveio da Zona de Afloramentos (ZA) do SAG (OAS/SAP, 2009), por meio de poços tubulares com profundidades (entre 47 até $128 \mathrm{~m}$ ) até o ano de 2009. Naquele ano ocorreu uma forte estiagem quando passou a também ser abastecido pela Companhia Riograndense de Saneamento/CORSAN. Atualmente as captações estão monitoradas por hidrômetros, estão cercadas com perímetro mínimo de proteção e as águas são cloradas. Informações detalhadas podem ser obtidas diretamente na página da WEB UFSM (http://www.ufsm.br/labhidrogeo). 
O objetivo desta pesquisa é apresentar a sociedade como vem sendo executada a gestão dos recursos hídricos subterrâneos no Campus/UFSM. Em um segundo artigo serão apresentados os resultados físico-químicos e bacteriológicos.

Uma vez que a água é gerenciada por órgãos governamentais, cabe a sociedade seu uso racional, bem como a preservação de sua qualidade. Desta forma, o Laboratório de Hidrogeologia da UFSM/LABHIDROGEO, junto com o Laboratório de Química Ambiental e Industrial da UFSM/LAQIA, Centro de Ciências da Saúde e Comissão Ambiental do Campus, Setor de Manutenção Hidráulica vem contribuindo na sua gestão. O LABHIDROGEO juntamente com o Grupo de Pesquisas em Recursos Hídricos/GEHRI vem produzindo trabalhos de pesquisas e orientações de alunos em recursos hídricos subterrâneos no interior do Campus, destacando-se MOREIRA (2005), MARION et al. (2007), MARION (2009), D'ÁVILA (2009), LÖBLER et al. (2010), SANTIAGO (2010), SANTIAGO et al. (2011), e LÖBLER et al. (2011).

De acordo com o sítio ofícial do governo do Estado do Rio Grande do Sul, "A outorga de direito de uso da água representa um instrumento, através do qual o Poder Público autoriza, concede ou ainda permite ao usuário fazer o uso deste bem público. É através deste que o Estado exerce, efetivamente, o domínio das águas preconizado pela Constituição Federal, regulando o compartilhamento entre os diversos usuários".

A Lei Estadual 10.350, de 30 de dezembro de 1994, em seu Artigo 29, considera que qualquer empreendimento ou atividade que alterar as condições quantitativas e/ou qualitativas das águas, superficiais ou subterrâneas, observando o Plano Estadual de Recursos Hídricos e os Planos de Bacia Hidrográfica, dependerá de outorga. Caberá ao Departamento de Recursos Hídricos a emissão de outorga para os usos que alterem as condições quantitativas das águas.

Os Decretos Estaduais no 37.033/1996 e no 42.047/2002, regulamentam o gerenciamento e à conservação das águas subterrâneas e dos aquíferos no Estado do Rio Grande do Sul (SEMA/RS/2012).

Rebouças (1992) já salientava que a hidrogeologia evoluiu de seu escopo tradicional de estudos dos aquíferos com o objetivo único de produção de água para consumo humano, industrial ou agrícola, para uma abordagem sistêmica e de objetivos múltiplos. Desta forma o pesquisador considerava as funções objetivo mais importantes: a) função estocagem/regularização (reservatório); b) função filtro (arranjos das partículas minerais e argilominerais/Capacidade de Troca de Cátions), c) função estratégica (reservas renováveis e não renováveis) e, d) função ambiental (preservação dos ecossistemas).

\section{Caracterização da área}

No município de Santa Maria, localizado no centro do Estado do Rio Grande do Sul/Brasil. No ano de 1960 foi criada a primeira Universidade Federal de Ensino Superior no interior do Estado a UFSM. Seu Campus localiza-se a $9 \mathrm{~km}$ da sede, no Bairro Camobi (Figura 1). Sua área original era de 528,6649 ha, posteriormente foi adquirida uma Área Nova com cerca de 600,7949 ha, onde estão instaladas duas captações por poços, sendo um na Torre da Rádio outra Experimentos da Zootecnia/Solos.

Em termos geomorfológicos, o Campus pertence à Depressão Central, prevalecem às coxilhas suaves levemente onduladas, associadas à presença de campos (gramíneas), isoladas plantações de eucaliptos e alguns cultivos por parte dos experimentos. 
As rochas sedimentares pertencentes ao Grupo Rosário do Sul (Giardin e Faccini, 2004), que se compõem pelas Formações Sanga do Cabral e Santa Maria (Membro Passo das Tropas e Membro Alemoa), além de aluviões associados a Terraços de Depósitos Cenozóicos. Quanto aos tipos de solos; predomina a Unidade Santa Maria (Argissolo Amarelo e Argissolo BrunoAcinzentado) e Unidade São Pedro (Argissolo Vermelho) Streck et al. (2008). As águas superficiais que drenam a área do Campus pertencem a Bacia Hidrográfica do Rio Vacacaí e Vacacaí-Mirim (G60) que pertence a Região Hidrográfica do Guaíba (G), SEMA (2004).

Ao longo dos anos, foram perfurados mais de 50 poços tubulares para abastecer cerca de 17.000 pessoas que circulam no Campus, em média diariamente. Atualmente cerca de 20 poços estão desativados e 24 poços estão ativos. Os usos das águas subterrâneas são múltiplos; principalmente no abastecimento humano, limpeza, jardinagem, lavagens, uso nos laboratórios, no Hospital Universitário, usina de Lacticínios, dessedentação de animais, em experimentos agrícolas, piscina térmica, dentre outros.

\section{METODOLOGIA}

Na delimitação da área do Campus utilizou-se como base a Carta Topográfica de Camobi, Folha SH.22-V-C-IV-2, MI-2965/2-SO, escala 1:25.000, Diretoria do Serviço Geográfico do Exército Brasileiro, 1980; a Planta Parcial de situação e localização do Campus da UFSM, de junho de 2002, em escala 1:5000 cedida pela Prefeitura da UFSM; e o Mapa da UFSM do Projeto Bacia Escola, em escala 1:7500 Maciel Filho (2000).

Na estruturação do Banco de Dados consta a localização geográfica de cada captação (no Sistema de coordenadas Universal Transvesa de Mercator/UTM, Datum Vertical Porto de Imbituba/SC e Datum Horizontal SAD-69 MG), o número do poço, a condição de funcionamento ( $\mathrm{PB}=$ poço com bomba submersa) e ( $\mathrm{P}=$ poço dotado de compressor, air-lift) usados até $\mathrm{o}$ ano de 2008. A identificação da empresa responsável pela perfuração e o ano, o nível estático (sem bombeamento), o nível dinâmico (rebaixamento de nível com bombeamento), a vazão (produção do poço em $\mathrm{m}^{3} / \mathrm{h}$ ), a altitude na boca do poço, o volume explotado (hidrômetro) e a Superfície Potenciométrica.

Os procedimentos para elaboração dos planos de informação (PIs) a partir da avaliação da potenciometria ou superfície potenciométrica foram obtidos para cada poço na altura da boca, pela relação entre a cota altimétrica do poço subtraindo-se o seu nível estático. Ela indica a carga de uma coluna de água sobre um Datum, neste caso o nível zero médio do mar. Esta superfície indica pontos de igual potencial, traçando-se perpendicularmente a essas a linha de fluxo subterrâneo, que indica uma tendência de movimento das águas subterrâneas sob a ação da gravidade e de parâmetros intrínsecos das rochas (aquíferos). Depende da relação entre a porosidade/ permeabilidade do meio sedimentar, dos tipos de estruturas sedimentares primárias, do tectonismo (falhas e/ou fraturas) continuidade ou não das camadas, do grau de cimentação, presença de concreções carbonáticas e/ou silicosas (Silvério da Silva et al. 2010) e outros parâmetros.

Partindo-se dos registros de nível estático, considerando a altitude na boca do poço e da potenciometria construíram-se planos de informações que demonstram sua variação. Ilustra-se cerca de vinte poços ativos até o ano de 2004. Os dois poços ativos situados na Área Nova, não foram representados nos mapas. Na elaboração do plano de informação utilizou-se o Programa Surfer 8, com o método de interpolação "Krigagem". Posteriormente esse plano foi exportado do 
Surfer e importado para o programa Corel Draw 15, onde recebeu a edição final. O uso desta técnica é detalhada em (LANDIM et al., 2002) e (LAMDIM e STURARO, 2002).

Para elaboração do mapa geológico do Campus da UFSM utilizou-se como base o Mapa Geológico da Folha de Camobi, SH.22-V-C-IV-2, MI-2965/2, escala 1:50.000, Maciel Filho, (1988). Também foram construídos cortes transversais com o perfil litológico dos poços PB3 (Planetário), PB5 (Centro de Ciências da Saúde), PB6 (Colégio Agrícola, desativado), PB8 (Estrada do Jardim Botânico), PB9 (Lacticínios), PB19 (Torrão Paulista), PB20 (Prédio Básicos), PB21 (Hospital de Clínica Veterinária, PB22 (Tambo), INPE Norte e INPE Sul estão ilustrados nas Figuras 1, 2, 3 e 4.

$\mathrm{Na}$ elaboração do balanço hídrico climático procedeu-se uma avaliação dos dados das variáveis climáticas (temperatura do ar, precipitação pluviométrica e evaporação). Estes foram disponibilizados pela Estação Meteorológica da UFSM em formato de planilhas. Efetivou-se o cálculo do Balanço Hídrico climático conforme o roteiro proposto por Thorntwaite \& Mather simplificado por Camargo apud Pereira et al. (2001). Na estimativa da ETP (evapotranspiração potencial), tomando-se como base os dados médios mensais para os anos de 2002, 2003 e 2004. Complementaram-se esses dados com os valores de balanço hídrico climático dos anos de 2000 e 2001 Osório et al. (2002).

O procedimento adotado no registro da flutuação do nível da água no poço PB17 (Biblioteca Central, em condição desativado) foi usado o freatímetro sonoro, dotado de cabo de 100 metros. Efetivando-se medições de frequência mensal durante o período de 17/07/2003 a $17 / 12 / 2003$. Já durante o período de 06/01/2004 a 22/07/2004 a freqüência das medições foi semanal. Posteriormente esses dados foram comparados com os valores do balanço hídrico climatológico desse período, realizando-se a média mensal do nível da água do poço PB17 para o ano de 2004. Uma obstrução parcial deste poço de monitoramento paralisou suas medições. No ano 2010 sofreu uma manutenção e vem sendo monitorado semanalmente por Löbler et al. (2010, 2011). Até a presente data os poços tubulares e/ou de monitormento no Campus ainda não estão dotados de registradores automáticos de nível (data loggers).

Neste sentido a Companhia de Pesquisas de Recursos Minerais/CPRM no Projeto RIMAS/Rede de Monitoramento Integrado de Águas Subterrâneas -RIMAS, esta instalando poços de monitoramento com registradores automáticos em vários pontos do país para avaliar diferentes aquíferos, registrar suas flutuações quali-quantitativas. Visando selecionar poços realizou-se uma avaliação através de vídeoendoscopia em dois poços tubulares desativados (PB) e (PB-20 Prédio 21 Básicos) do Campus da UFSM, no início do ano de 2012. Estes registros, em formato digital estão disponíveis no acervo do Labhidrogeo. E ainda não foram disponibilizados na página na web por serem arquivos de imagens, em formato muito pesados.

Ainda, durante o ano de 2011 foram perfurados dois novos poços rasos de monitoramento de nível e qualidade. Estes foram construídos na região alagada, próximo do Restaurante Universitário e Casa dos Estudantes, visam avaliar possíveis alterações na qualidade de água subterrânea de longa duração (RECKZIEGEL, 2012).

\section{RESULTADOS E DISCUSSÃO}

Dos 24 poços ativos de diâmetros iguais ou superiores a 4 polegadas $(100 \mathrm{~mm})$ instalados no Campus da UFSM, todos explotam água subterrânea da (ZA) do SAG (OAS/SAP/ 2009) por meio de bomba submersa, para abastecimentos múltiplos Figura 1.

Na Figura 2 se apresenta alguns detalhes construtivos do poço tubular PB-25 (Eucaliptos, Estrada do Jardim Botânico). Esta captação foi perfurada no ano de 2008 e já se encontra de 
acordo com as normas Decreto № 42.047/2002 para a obtenção da outorga dos recursos hídricos subterrâneos. De modo a atender a demanda necessária e abastecer cerca de 172 reservatórios do Campus da UFSM, os poços tubulares estão distribuídos em diversos setores ou em rede (MOREIRA, 2005).

Em relação às características hidrogeológicas, entende-se por nível estático à profundidade da água subterrânea em repouso (sem bombeamento no poço). Observou-se que os a faixa de variação dos valores de nível estático foi entre 15,35m, poço PB 12 (Parque de Exposições) na porção sudoeste. Por outro lado, o poço de nível estático mais profundo foi de 39,38m, PB14 (Jardim Botânico) ambos encontram-se localizados na porção Noroeste dos mapas (Figuras 1 e 5). Estimou-se um valor médio de $21,80 \mathrm{~m}$ para o nível da água subterrânea ou lençol freático, aqüíferos livres.

Estes tipos de registros são úteis na avaliação da vulnerabilidade dos aquíferos à contaminação. Hirata et al. (1997) e Foster et al. (2003) consideram as captações por poços que apresentam nível freático mais raso, são aquelas que apresentam os maiores riscos de contaminação, devido a maior facilidade de contaminantes percolarem nas camadas aquíferas mais rasas. Por outro lado, há uma dificuldade maior de penetração de contaminantes oriundos da superfície do terreno produtos de atividades de origem antrópica em atingir as camadas aquíferas mais profundas, função filtro (REBOUÇAS, 1982). Também se considera que as camadas arenosas apresentam maiores facilidades de difusão de contaminantes quando comparadas as camadas argilosas, praticamente impermeáveis.

Em relação aos aspectos geológicos o Campus, situa-se na Província Gondwânica, SubProvíncia Rosário do Sul - Formação Santa Maria que se subdivide nos Membros Alemoa e Passo das Tropas, conforme a subdivisão do Estado do Rio Grande do Sul em Províncias e Sub-Províncias Hidrogeológicas, estabelecida por Hausmam (1995).

Na porção Norte da área ilustrada na Figura 3 afloram os Terraços Fluviais. A Formação Sanga do Cabral não aflora no Campus, mas foi identificada a partir dos perfis litológicos de alguns poços tubulares e contribui na dinâmica subterrânea da água pertencente a (ZA) do SAG.

O Membro Passo das Tropas, da Formação Santa Maria ocorre aflorante na porção Central do Campus e é constituído predominantemente por arenitos grosseiros a médios, por vezes conglomeráticos, com estratificação cruzada acanalada na base, interdigitado por siltitos arenosos com tonalidade roxo-avermelhado de origem em peloambiente fluvial. Ainda correm interdigitadas camadas de constituição arenitos finos a siltitos laminados, de cor rosa à lilás, de ambiente flúvio-lacustre Maciel Filho et al. (1988) e Gaspareto et al. (1990) Figuras (3 e 4).

Conforme disposto no mapa hidrogeológico da Companhia de Pesquisa e Recursos Minerais (CPRM, 1994) o Membro Passo das Tropas, em função de suas litologias serem dominantemente arenosas e muito permeáveis constituem um aquífero contínuo, livre e/ou confinado de grande extensão. Esta unidade é considerada o melhor aquífero na região, apresentando excelentes vazões e águas, em geral, de boa qualidade. Porém são muito vulneráveis devido a sua elevada relação porosidade/permeabilidade o que pode facilitar o movimento de uma pluma de contaminação.

O Membro Passo das Tropas é interdigitado por siltitos argilosos maciços, de cor vermelha, com níveis esbranquiçados de concreções calcárias, calcretes do Membro Alemoa Silvério da Silva (1990, 1997 e 2010). Formam camadas sub-horizontais de ambiente continental (Maciel Filho et al., 1988). O Membro Alemoa é constituído por lamitos impermeáveis que funcionam como Aquiclude, não armazenando nem transmitindo água Maciel Filho (1988), (CPRM, 1994). Estas rochas de composição silto-argilosas apresentam baixa condutividade hidráulica (superiores a $10^{-}$ 
$7 \mathrm{~m} / \mathrm{dia}$ ). Portanto são os melhores materiais geológicos para "filtrarem" possíveis contaminantes oriundos da superfície terrestre, sejam eles de natureza inorgânica, orgânica ou mista.

Na porção Norte (Figura 3) ocorrem os sedimentos do Período Quaternário, pertencentes aos Terraços Fluviais, cujas litologias predominantes são os conglomerados, os arenitos médios argilosos com estratificação cruzada e planar e os siltitos arenosos, de cores cinza-clara, rosa e amarela, de ambiente fluvial (Maciel Filho et al., 1988). Estes afloramentos ocorrem principalmente na margem esquerda do Arroio "sem denominação", nos fundos do Prédio 26 (Centro de Ciências da Saúde) em contato direto com siltitos argilosos vermelhos do Membro Alemoa pertencentes à Formação Santa Maria.

Estes Terraços Fluviais são considerados aquíferos irregulares, livres, e compõem-se de sedimentos pouco consolidados, bastante argilosos, de pequena espessura, possuindo uma média a baixa permeabilidade, e a água é de boa qualidade (CPRM, 1994). Embora as captações por poços penetrem nestas litologias, não ocorrem extrações de água subterrânea nestas rochas.

Dos cerca de vinte e quatro poços ativos presentes no Campus, onze possuem os perfis litológicos detalhados na Figura 4. Notar a variabilidade de materiais sedimentares dispostos lateralmente quanto verticalmente produto de paleoambiente e que influenciam nos parâmetros hidrodinâmicos.

A partir da qual se identifica a predominância dos arenitos nos perfis dos poços. Uma exceção o poço PB 19 (Tambo) que apresenta menores proporções dessa litologia. Este resultado é devido às características paleoambientais do meio deposicional. Esses arenitos apresentam características diferentes, aparecem sob a forma de arenitos: muito fino, fino, médio, grosso, silicificado, siltoso, argiloso, com grânulos ou com cascalhos, também apresentam colorações diferentes variando entre branco, vários tons de vermelho, rosado, bege, marrom, pálido, amarelado, ocre, acinzentado ou terracota. Estas características do meio conferem diferentes parâmetros hidráulicos os quais se refletem nas diferentes vazões dos poços e ainda, nos politipos de águas.

Há ocorrência pontual de níveis silicificados, os quais funcionam como uma camada impermeável devido à presença do cimento silicoso entre os poros do arenito (SILVÉRIO DA SILVA, 1997). Também ocorrem pontualmente concreções carbonáticas ou calcretes, bastante duras que podem liberar bicarbonatos e carbonatos na água (SILVÉRIO DA SILVA et al. 2010).

As características litológicas do pacote de rochas que alimenta esses poços estão representadas principalmente por arenitos de granulometria muito fina, fina ou média, em alguns casos intercalados por argilitos (PB5, PB6, PB8, PB9, INPE Norte), sedimentos argilosos (PB19, INPE Sul). Já nos poços (PB3, PB5) predomina a fração silte e/ou siltitos. Essas características associadas às entradas de água caracterizam um tipo de aquífero confinado, drenante e de baixa vazão.

O poço PB20 (Prédio dos Básicos), por exemplo, embora representado basicamente por arenitos, também apresenta intercalações argilosas. Considerando o teste de vazão desse poço, sua capacidade específica foi de $\left(0,156 \mathrm{~m}^{3} / \mathrm{h} / \mathrm{m}\right)$. Foi perfurado com diâmetro de $\left(12 \frac{114}{4}=\right.$ $311,15 \mathrm{~mm})$, a transmissividade do aquífero foi estimada da ordem de $\left(6 \mathrm{~m}^{2} / \mathrm{dia}\right)$. A espessura da seção filtrante foi de $(25,07 \mathrm{~m}$ de comprimento) e a condutividade hidráulica (entre 0,1 e 1,0 $\mathrm{m} /$ dia). Classificando-se o aquífero que alimentava esse poço como pobre e de má capacidade de drenagem (0,24 m/dia), (CPRM, 1996). O Poço encontra-se desativado e deverá fazer parte da Rede de Monitorameto da CPRM/RIMAS.

Essas formações geológicas, conforme suas litologias constituintes apresentam diferentes comportamentos hidroestratigráficos e são importantes tanto para o entendimento do fluxo das águas subterrâneas como na recarga subterrânea bem como se refletem na vazão dos poços. 
Verificou-se que as vazões acima de $13 \mathrm{~m}^{3} / \mathrm{h}$ encontram-se na porção central do Campus, associado ao poço PB3 (Planetário), $20 \mathrm{~m}^{3} / \mathrm{h}$, o qual penetra um bolsão da Formação Santa Maria Membro Passo das Tropas e parte dos argilitos do Membro Alemoa.

Notou-se que as menores vazões encontram-se na porção Sudoeste (Figura 3) e extremidade ao Norte, vinculados aos poços PB9, P12 e INPE Norte, cujos valores atingem vazões inferiores a $7 \mathrm{~m}^{3} / \mathrm{h}$. A vazão de explotação dos poços tubulares ativos do Campus foi avaliada entre um mínimo de $2 \mathrm{~m}^{3} / \mathrm{h}$ no poço $\mathrm{P} 12$ (Suinocultura) e um máximo $20 \mathrm{~m}^{3} / \mathrm{h}$ no poço $\mathrm{PB} 3$.

O Quadro 1 apresenta a variação do nível da água no poço tubular PB17 (Biblioteca central), durante o ano de 2004 (MOREIRA, 2005). Informa-se que o poço tubular mais próximo em funcionamento PB15 (Madame) dista deste cerca $368 \mathrm{~m}$. Por constituir um aquífero livre a semi-confinado e devido a predominância das camadas silto-argilosas da Formação Santa Maria, Membro Alemoa, acredita-se não estar sendo afetado pelo cone de rebaixamento do PB15 ativo.

O nível estático da água no poço PB17 em Janeiro de 2004 foi de 8,73 m. Neste período havia um déficit hídrico para a área de $50,89 \mathrm{~mm}$ ilustrado nos Quadros (1 e 2). Em Fevereiro o nível foi $8,92 \mathrm{~m}$ enquanto no balanço hídrico o déficit foi igual ao excedente. No mês de Março houve um déficit no balanço hídrico e o nível da água no poço foi de 9,32 $\mathrm{m}$. Em Abril ocorreu novamente um equilíbrio entre déficit e excedente hídrico, mas o nível da água foi de 8,72 $\mathrm{m}$ o mesmo ocorreu em Maio. No entanto, o nível caiu para 9,01m decaindo ainda mais em Junho, para cerca de 9,96 m. Neste mês ocorreu um excedente hídrico de 16,09 $\mathrm{mm}$. Este fato indica que houve recuperação do nível de água para 8,98 m entre os dias 10 e 15 de Julho de 2004 . Posteriormente ocorreu o desmoronamento parcial do poço, inviabilizando novas medições.

A recarga aquífera não depende unicamente das condições climáticas, mas também das características naturais do meio. Portanto a existência de camadas sedimentares conectadas em um determinado local pode trazer águas subterrâneas de fora da área de estudo, devido sua constituição em camadas arenosas contínuas, porosas e permeáveis. O valor máximo mensurado no período ocorreu em 28 de Janeiro de 2004, de 8,28m. Já o nível mínimo foi de 16,10 m, em 21 de Julho de 2004, havendo uma flutuação média no poço de $7,84 \mathrm{~m}$, indicativa de recarga subterrânea.

Uma vez que parte do Campus situa-se na planície aluvial de afluentes dos Rios Vacacaí e Vacacaí Mirim, onde o lençol freático esta constituído principalmente por aquíferos livres. Este nível se encontra próximo da superfície do terreno, apresentando um valor estimado médio de 21,80m. Deve-se salientar que o uso do solo em Planícies Aluviais próximas, ocorre o cultivo do arroz irrigado, no período primavera-verão (Novembro-Março). Portanto ocorrendo um acúmulo de água na superfície do terreno. Este fato poderia influenciar na recarga lateral nos poços tubulares da área do estudo. Esta hipótese deve ser melhor investigada.

Para verificar a influência das condições climáticas no processo de recarga aquífera direta, executaram-se medições mensais e semanais do nível da água do poço PB17 Quadro 1. A média mensal do ano de 2004 obedeceu à escala mensal. Buscando-se assim comparar com os dados de déficit e excedente hídrico no balanço climatológico avaliado no período de 2000 a 2004 Quadro 2. 
QUADRO 1. Variação do nível da água do poço PB17 durante o ano de 2004.

\begin{tabular}{|c|c|c|}
\hline Data & Nível da água subterrânea $(\mathbf{m})$ & Déficit Hídrico (mm) \\
\hline Janeiro & 8,73 & 50,89 \\
\hline Fevereiro & 8,92 & 20,00 \\
\hline Março & 9,32 & 0,00 \\
\hline Abril & 8,72 & 0,00 \\
\hline Maio & 9,01 & 0,00 \\
\hline Junho & 9,96 & 0,00 \\
\hline Julho & 8,98 & \\
\hline Faixa variação & 0,60 & \\
\hline
\end{tabular}

Obs. Nível da água medido em Outubro de 2010 indicou 10,85m, indicando pequeno rebaixamento.

Em relação as vazões de expolotação notou-se que os menores valores encontram-se na porção Sudoeste e Norte, vinculados aos poços PB9, P12 e INPE Norte, cujos valores atingem vazões inferiores à $7 \mathrm{~m}^{3} / \mathrm{h}$. A vazão de explotação dos poços tubulares ativos do Campus no ano de 2004 variou de um mínimo de $2 \mathrm{~m}^{3} / \mathrm{h}$ no poço P12 (Suinocultura) até um máximo de $20 \mathrm{~m}^{3} / \mathrm{h}$ no poço PB3.

Quadro 2. Balanço hídrico climático entre os anos de 2000 até 2004.

\begin{tabular}{|c|c|c|c|c|c|c|c|c|c|c|c|c|c|}
\hline Anos & Meses & $\mathrm{T}(\mathrm{O} C)$ & $\begin{array}{c}\text { ETT } \\
(\mathrm{mm})\end{array}$ & Correção & ETP & Prec. & Prec.-ETP & $\begin{array}{l}\text { Neg. } \\
\text { Acum. }\end{array}$ & $\begin{array}{l}\text { ARM } \\
(\mathrm{mm})\end{array}$ & $\begin{array}{c}\text { ALT } \\
(\mathrm{mm})\end{array}$ & $\begin{array}{c}\text { ETR } \\
(\mathrm{mm})\end{array}$ & $\begin{array}{c}\text { DEF } \\
(\mathrm{mm})\end{array}$ & $\begin{array}{c}\text { EXC } \\
(\mathrm{mm})\end{array}$ \\
\hline \multirow{12}{*}{ ঠ } & Janeiro & 5,30 & 4,00 & 1,19 & 143,00 & 246,00 & 103,00 & 0,00 & 100 & 0,00 & 143,00 & 0,00 & 103,00 \\
\hline & Fevereiro & 24,50 & 3,70 & 1,03 & 114,00 & 90,00 & $-24,00$ & $-24,00$ & 76,00 & $-24,00$ & 114,00 & 0,00 & 0,00 \\
\hline & Março & 21,40 & 2,90 & 1,06 & 92,00 & 249,00 & 157,00 & 0,00 & 100 & 24,00 & 92,00 & 0,00 & 133,00 \\
\hline & Abril & 20,20 & 2,60 & 0,95 & 74,00 & 78,00 & 4,00 & 0,00 & 100 & 0,00 & 74,00 & 0,00 & 4,00 \\
\hline & Maio & 15,50 & 1,50 & 0,92 & 41,00 & 149,00 & 108,00 & 0,00 & 100 & 0,00 & 41,00 & 0,00 & 108,00 \\
\hline & Junho & 16,00 & 1,70 & 0,86 & 42,00 & 262,00 & 218,00 & 0,00 & 100 & 0,00 & 44,00 & 0,00 & 218,00 \\
\hline & Julho & 11,00 & 1,00 & 0,90 & 27,00 & 95,00 & 68,00 & 0,00 & 100 & 0,00 & 27,00 & 0,00 & 68,00 \\
\hline & Agosto & 14,00 & 1,20 & 0,96 & 35,00 & 99,00 & 64,00 & 0,00 & 100 & 0,00 & 35,00 & 0,00 & 64,00 \\
\hline & Setembro & 16,20 & 1,70 & 1,00 & 51,00 & 242,00 & 191,00 & 0,00 & 100 & 0,00 & 51,00 & 0,00 & 191,00 \\
\hline & Outubro & 19,40 & 2,40 & 1,12 & 81,00 & 185,00 & 104,00 & 0,00 & 100 & 0,00 & 81,00 & 0,00 & 104,00 \\
\hline & Novembro & 20,30 & 2,60 & 1,13 & 88,00 & 204,00 & 116,00 & 0,00 & 100 & 0,00 & 88,00 & 0,00 & 116,00 \\
\hline & Dezembro & 23,90 & 3,50 & 1,20 & 126,00 & 154,00 & 28,00 & 0,00 & 100 & 0,00 & 126,00 & 0,00 & 28,00 \\
\hline \multirow{12}{*}{ 몽 } & & 25,00 & 4,00 & 1,19 & 143,00 & 310,00 & 167,00 & 0,00 & 100 & 0,00 & 143,00 & 0,00 & 167,00 \\
\hline & Fevereiro & 26,00 & 4,20 & 1,03 & 130,00 & 125,00 & $-5,00$ & $-5,00$ & 95 & $-5,00$ & 130,00 & 0,00 & 0,00 \\
\hline & Março & 24,40 & 3,70 & 1,06 & 118,00 & 144,00 & 26,00 & 0,00 & 100 & 5,00 & 118,00 & 0,00 & 21,00 \\
\hline & Abril & 20,50 & 2,50 & 0,95 & 71,00 & 250,00 & 179,00 & 0,00 & 100 & 0,00 & 71,00 & 0,00 & 179,00 \\
\hline & Maio & 15,50 & 1,30 & 0,92 & 36,00 & 57,00 & 21,00 & 0,00 & 100 & 0,00 & 36,00 & 0,00 & 21,00 \\
\hline & Junho & 15,30 & 1,30 & 0,86 & 33,00 & 179,00 & 146,00 & 0,00 & 100 & 0,00 & 33,00 & 0,00 & 146,00 \\
\hline & Julho & 14,00 & 1,10 & 0,90 & 36,00 & 201,00 & 171,00 & 0,00 & 100 & 0,00 & 30,00 & 0,00 & 171,00 \\
\hline & Agosto & 18,00 & 2,00 & 0,96 & 58,00 & 68,00 & 10,00 & 0,00 & 100 & 0,00 & 58,00 & 0,00 & 10,00 \\
\hline & Setembro & 17,10 & 1,80 & 1,00 & 54,00 & 237,00 & 183,00 & 0,00 & 100 & 0,00 & 54,00 & 0,00 & 183,00 \\
\hline & Outubro & 21,00 & 2,80 & 1,12 & \begin{tabular}{|l|}
94,00 \\
\end{tabular} & 165,00 & 71,00 & 0,00 & 100 & 0,00 & 94,00 & 0,00 & 71,00 \\
\hline & Novembro & 22,00 & 3,10 & 1,13 & 105,00 & 109,00 & 4,00 & 0,00 & 100 & 0,00 & 105,00 & 0,00 & 4,00 \\
\hline & Dezembro & 23,10 & 3,40 & 1,20 & 122,00 & 78,00 & $-44,00$ & $-44,00$ & 64,41 & $-35,60$ & 122,00 & 0,00 & 0,00 \\
\hline \multirow{3}{*}{ రి } & Janeiro & 24,90 & 4,15 & 1,19 & 148,16 & 111,80 & $-36,36$ & $-80,36$ & 44,76 & $-11,22$ & 123,00 & 25,16 & 0,00 \\
\hline & Fevereiro & 23,50 & 3,60 & 1,03 & 111,24 & 101,10 & $-10,14$ & $-90,50$ & 40,46 & $-4,30$ & 105,40 & 5,84 & 0,00 \\
\hline & Março & 25,30 & 4,06 & 1,06 & 129,11 & 252,10 & 122,99 & 0,00 & 100 & 59,54 & 129,11 & 0,00 & 63,45 \\
\hline
\end{tabular}




\begin{tabular}{|c|c|c|c|c|c|c|c|c|c|c|c|c|c|}
\hline & Abril & 19,70 & 2,54 & 0,95 & 72,39 & 183,70 & 111,31 & 0,00 & 100 & 0,00 & 72,39 & 0,00 & 111,31 \\
\hline & Maio & 18,20 & 2,16 & 0,92 & 59,62 & 113,80 & 54,18 & 0,00 & 100 & 0,00 & 59,62 & 0,00 & 54,18 \\
\hline & Junho & 13,90 & 1,17 & 0,86 & 30,19 & 174,00 & 143,81 & 0,00 & 100 & 0,00 & 30,19 & 0,00 & 143,81 \\
\hline & Julho & 3,40 & 1,08 & 0,90 & 29,16 & 238,30 & 209,14 & 00 & 00 & 0,00 & 29,16 & 0,00 & 209,14 \\
\hline & Agosto & 5,20 & 1,74 & ,96 & 50,11 & 283,80 & 233,69 &, 00 & 100 &, 00 & 50,11 & 0,00 & 233,69 \\
\hline & Setembro & 19,40 & 2,48 & 1,00 & 74,40 & 306,80 & 232,40 & 0,00 & 100 & 0,00 & 74,40 & 0,00 & 232,40 \\
\hline & Outubro & 20,80 & 2,84 & 1,12 & 95,42 & 349,80 & 254,38 & 0,00 & 100 & 0,00 & 95,42 & 0,00 & 254,38 \\
\hline & Novembro & 22,30 & 3,22 & 1,13 & 109,16 & 243,40 & 134,24 & 0,00 & 100 & 0,00 & 109,16 & 0,00 & 134,24 \\
\hline & Dezembro & 23,90 & 3,68 & 1,20 & 132,48 & 232,80 & 100,32 & 0,00 & 100 & 0,00 & 132,48 & 0,00 & 100,32 \\
\hline \multirow{2}{*}{ ஜֶర్ల } & Janeiro & 25,30 & 4,06 & 1,19 & 164,22 & 177,80 & 13,58 & 0,00 & 100 & 0,00 & 164,22 & 0,00 & 13,58 \\
\hline & Fevereiro & 25,10 & 4,02 & 1,03 & 124,22 & 204,70 & 80,48 & 0,00 & 100 & 0,00 & 124,22 & 0,00 & 80,48 \\
\hline \multirow{11}{*}{ 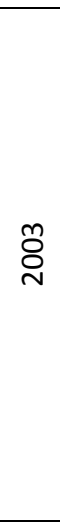 } & Meses & $\mathrm{T}(\mathrm{O} \mathrm{C})$ & $\begin{array}{c}\text { ETT } \\
(\mathrm{mm})\end{array}$ & Correção & ETP & Prec. & Prec.-ETP & $\begin{array}{c}\text { Neg. } \\
\text { Acum. }\end{array}$ & \begin{tabular}{|l|} 
ARM \\
$(\mathrm{mm})$
\end{tabular} & $\begin{array}{c}\text { ALT } \\
(\mathrm{mm})\end{array}$ & \begin{tabular}{|c|} 
ETR \\
$(\mathrm{mm})$
\end{tabular} & $\begin{array}{c}\text { DEF } \\
(\mathrm{mm})\end{array}$ & \begin{tabular}{|c|} 
EXC \\
$(\mathrm{mm})$
\end{tabular} \\
\hline & Março & 22,60 & 3,34 & 1,06 & 106,21 & 342,40 & 236,19 & 0,00 & 100 & 0,00 & 106,21 & 0,00 & 236,19 \\
\hline & Abril & 18,80 & 2,34 & & 66,69 & 190,00 & & & 100 & & 66,69 &, 00 & 123,31 \\
\hline & Maio & 16,50 & 1,80 & 0,92 & 49,68 & 69,10 & 19,42 & 0,0 & 100 & 0,00 & 49,68 & 0,00 & 19,42 \\
\hline & Junho & 15,90 & 1,68 & 0,86 & 43,34 & 170,50 & 127,16 & 0,00 & 100 & 0,00 & 43,34 & 0,00 & 127,16 \\
\hline & Julho & 13,40 & 1,08 & 0,90 & 29,16 & 113,00 & 83,84 & 0,00 & 100 & 0,00 & 29,16 & 0,00 & 83,84 \\
\hline & Agosto & 13,50 & 1,05 & 0,96 & 30,24 & 73,90 & 43,66 & 0,00 & 100 & 0,00 & 30,24 & 0,00 & 43,66 \\
\hline & Setembro & 15,90 & 1,68 & 1,00 & 50,40 & 57,00 & 6,60 & 0,00 & 100 & 0,00 & 50,40 & 0,00 & 6,60 \\
\hline & Outubro & 20,00 & 2,60 & 12 & 87,36 & 193,40 & 106,04 & 0,00 & 100 & 0,00 & 87,36 & 0,00 & 106,04 \\
\hline & Novembro & 21,60 & 3,02 & 13 & 102,38 & 228,60 & 126 & $\overline{0,0}$ & 100 & 0 & 102,38 & 0,00 & 126,22 \\
\hline & Dezembro & 21,90 & 3,08 & & 0,88 & 357,30 & 246 & 0 & 100 & & 110,88 &, 00 & 246,42 \\
\hline \multirow{12}{*}{ ర్ } & eiro & 25,00 & 4,00 & & 2,80 & 21,70 & -121 & $-121,10$ & 29,79 & \begin{tabular}{|l|}
$-70,21$ \\
\end{tabular} & 91,91 & 50,89 & 0,00 \\
\hline & Fevereiro & 23,00 & 3,50 & 1,0 & 108,15 & 110,80 & 2,6 & $-112,57$ & 32,44 & 2,65 & 108,15 & 0,00 & 0,00 \\
\hline & Março & 24,30 & 3,85 & 1,06 & 122,43 & 94,10 & $-28,33$ & $-148,90$ & 24,44 & $-8,00$ & 102,10 & 20,33 & 0,00 \\
\hline & Abril & 21,20 & 2,94 & 95 & 83,79 & 101,50 & 17,71 & \begin{tabular}{|l|}
$-86,39$ \\
\end{tabular} & 42,15 & 17,71 & 83,79 & 0,00 & 0,00 \\
\hline & Maio & 14,50 & 1,35 & 0,92 & 37,26 & 80,50 & 43,24 & $-15,79$ & 85,27 & 43,12 & 37,26 & 0,00 & 0,00 \\
\hline & Junho & 15,50 & 1,60 & 0,86 & 41,28 & 72,10 & 30,82 & 0,00 & 100 & 14,73 & 41,28 & 0,00 & 16,09 \\
\hline & Julho & 13,10 & 0,93 & 0,90 & 25,11 & 72,50 & 47,39 & 0,00 & 100 & 0,00 & 25,11 & 0,00 & 47,39 \\
\hline & Agosto & 15,20 & 1,54 & 0,96 & 44,35 & 85,40 & 41,05 & 0,00 & 100 & 0,00 & 44,35 & 0,00 & 41,05 \\
\hline & Setembro & 18,40 & 2,22 & 1,00 & 66,60 & 96,30 & 29,70 & 0,00 & 100 & 0,00 & 66,60 & 0,00 & 29,70 \\
\hline & Outubro & 18,50 & 2,25 & & 75,60 & 119,70 & & 0,0 & 100 & 0 & 75,60 & 0,00 & 44,10 \\
\hline & Novembro & 21,10 & 2,92 & 1,13 & 98,99 & 144,70 & 45,71 & 0,00 & 100 & 0,00 & 98,99 & 0,00 & 45,71 \\
\hline & Dezembro & & & & & & & & & & & & \\
\hline & $\begin{array}{r}=\text { temperat } \\
P=p\end{array}$ & ALT & 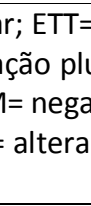 & $\sigma$ & $\because$ & . & L & te nic & ico. & o & solc & & \\
\hline
\end{tabular}

Deve-se considerar às estimativas de recarga aquífera direta dependem principalmente dos períodos de precipitação, através dos quais os poços são abastecidos naturalmente durante a infiltração da água destas chuvas. Neste caso na avaliação da recarga realizou-se o balanço hídrico climático verificando as condições de excedente ou déficit hídrico.

A partir da estimativa do balanço hídrico climatológico constatou-se pequena variação na temperatura média mensal entre os anos de 2000 até 2004, sendo que as maiores temperaturas ocorreram no mês de Janeiro (verão no sul do país) em todos os anos. O ano de 2001 foi uma excessão, no qual ocorreu a maior temperatura $26^{\circ} \mathrm{C}$ em Fevereiro. No ano de 2002 a maior temperatura foi de $25,3^{\circ} \mathrm{C}$ no mês de Março. Posteriormente as temperaturas sofreram 
decréscimo em quase todos os anos com pequenas alterações, sendo que em Julho de 2000, a média mensal alcançou $11^{\circ} \mathrm{C}$, caracterizando-o como o mês mais frio no período avaliado. Após o mês de Julho, as temperaturas voltaram a subir, gradativamente até o mês de Dezembro, cuja máxima foi de $23,9^{\circ} \mathrm{C}$ nos anos de 2000 e 2002. No ano de 2004 houve um menor índice de precipitação pluviométrica, totalizando $999,3 \mathrm{~mm}$. Já o ano de 2002 foi considerado o mais chuvoso, com cerca de $2.591,4 \mathrm{~mm}$.

Quanto aos valores de excedente ou déficit hídrico determinantes das condições quantitativas do armazenamento de água, todos os anos apresentaram excedentes hídricos, com exceção dos meses de Janeiro e Fevereiro de 2002 e também Janeiro e Março de 2004, onde se constatou déficit hídrico. Nos meses de Fevereiro de 2000, Fevereiro e Dezembro de 2001, não houve excedente nem déficit hídrico, pois embora, a precipitação tenha sido menor do que a evapotranspiração real havia um excedente hídrico do mês anterior. Em Fevereiro, Abril e Maio de 2004, não houve excedente nem déficit hídrico, uma vez que os valores de precipitação superaram os valores de evapotranspiração real.

Outra característica importante, no estudo dos aquíferos é o reconhecimento da superfície potenciométrica (Figura 5), pois além de expressar o tempo de sua recarga em função da distância da superfície do terreno, pode representar a fragilidade do meio à contaminação. Baixos valores da superfície potenciométrica indicam sua proximidade da superfície do terreno, enquanto valores elevados representam maiores profundidades em relação à superfície, portanto uma maior carga hidráulica sobre o Datum de referência. Torna-se relevante quando se verifica a qualidade das águas subterrâneas, avaliando-se as direções preferenciais de fluxo subterrâneo se houver uma contaminação na superfície do solo oriunda de atividades antrópicas.

A partir do ano 2000 foi constituída a Comissão Ambiental do Campus quando se buscou adequação as normas ambientais dos recursos hídricos subterrâneos, integrando diversos setores. 


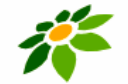

Monografias Ambientais

REMOANGSM
SILVA et al., v(9), no 9, p. 1953 - 1969, 2012.

(e-ISSN: 2236-1308)

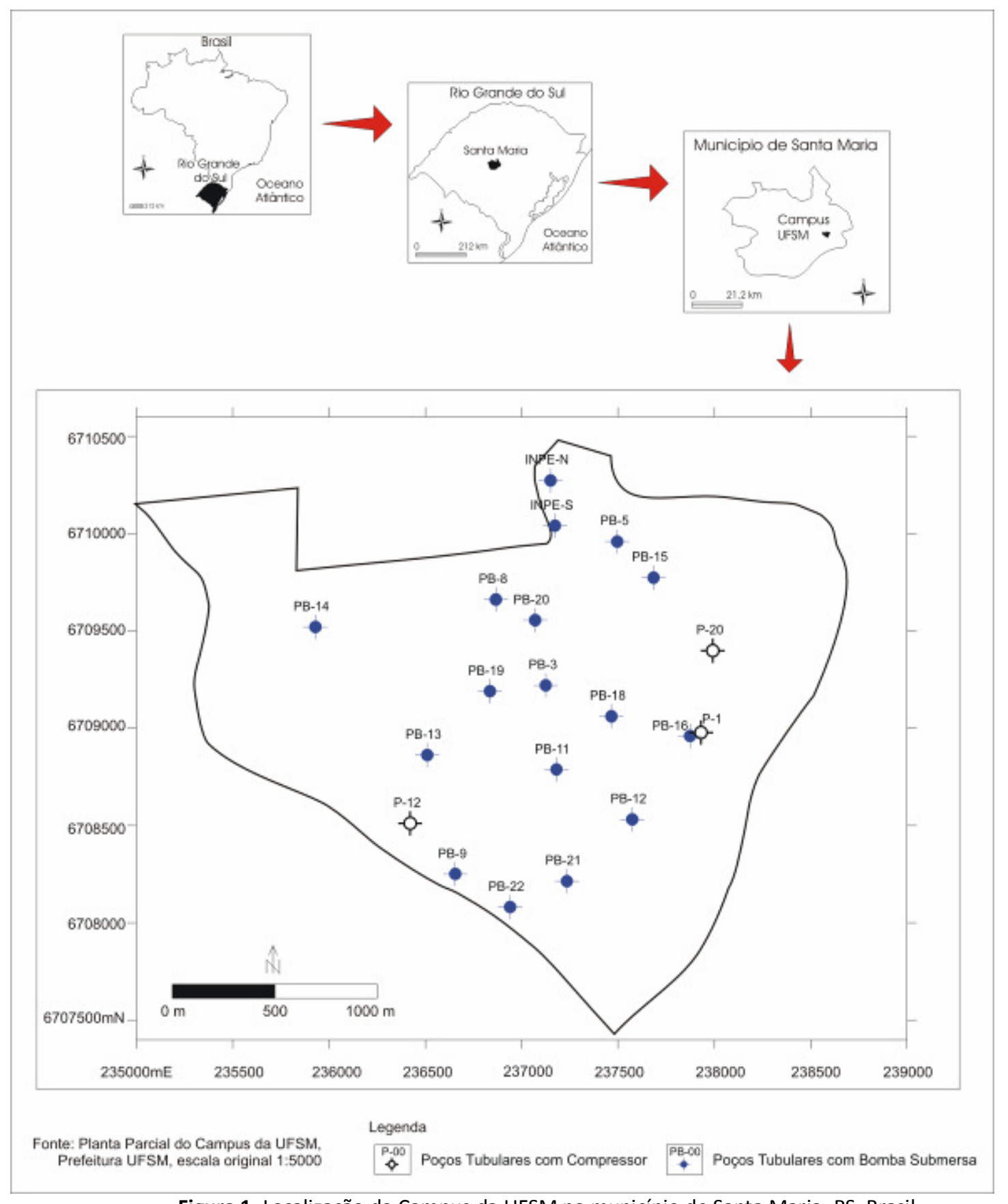

Figura 1. Localização do Campus da UFSM no município de Santa Maria, RS, Brasil. 


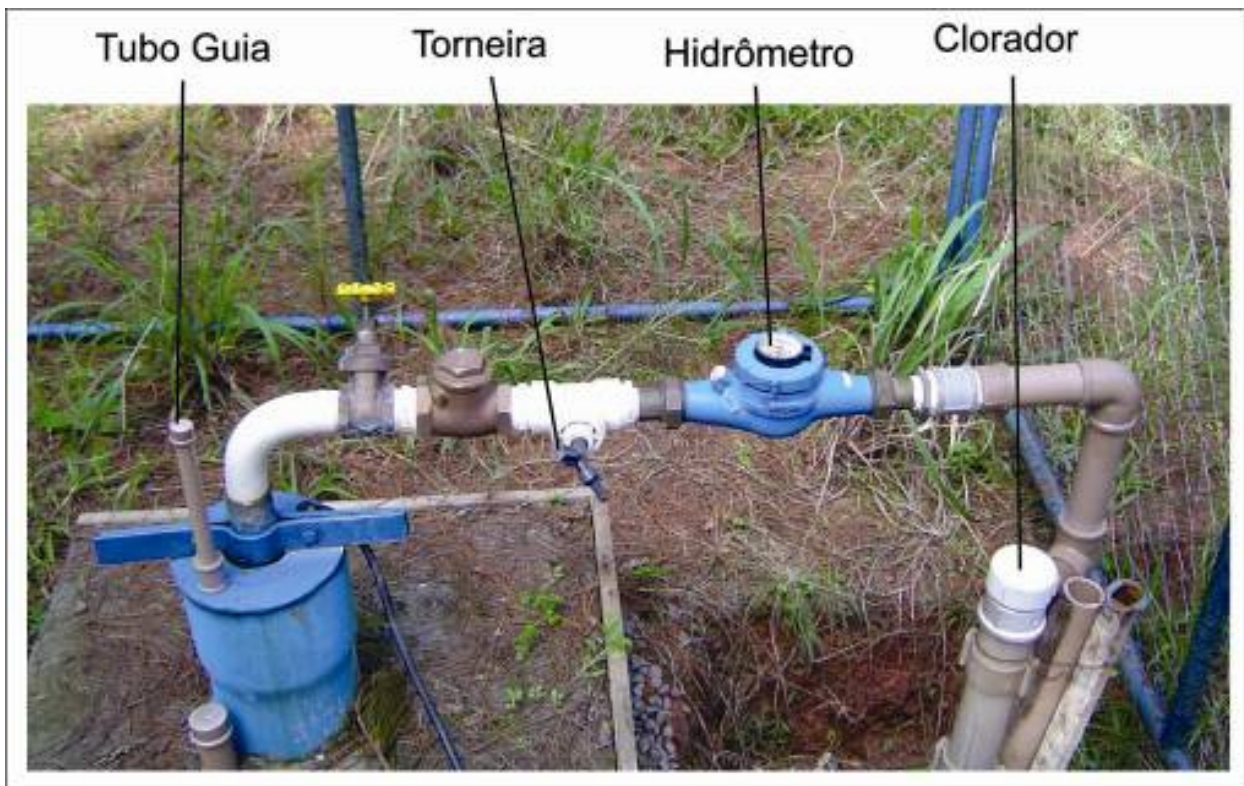

Figura 2. Aspectos construtivos do Poço Estrada do Jardim Botânico (PB 25). Fonte: Arquivo LABHIDROGEO.

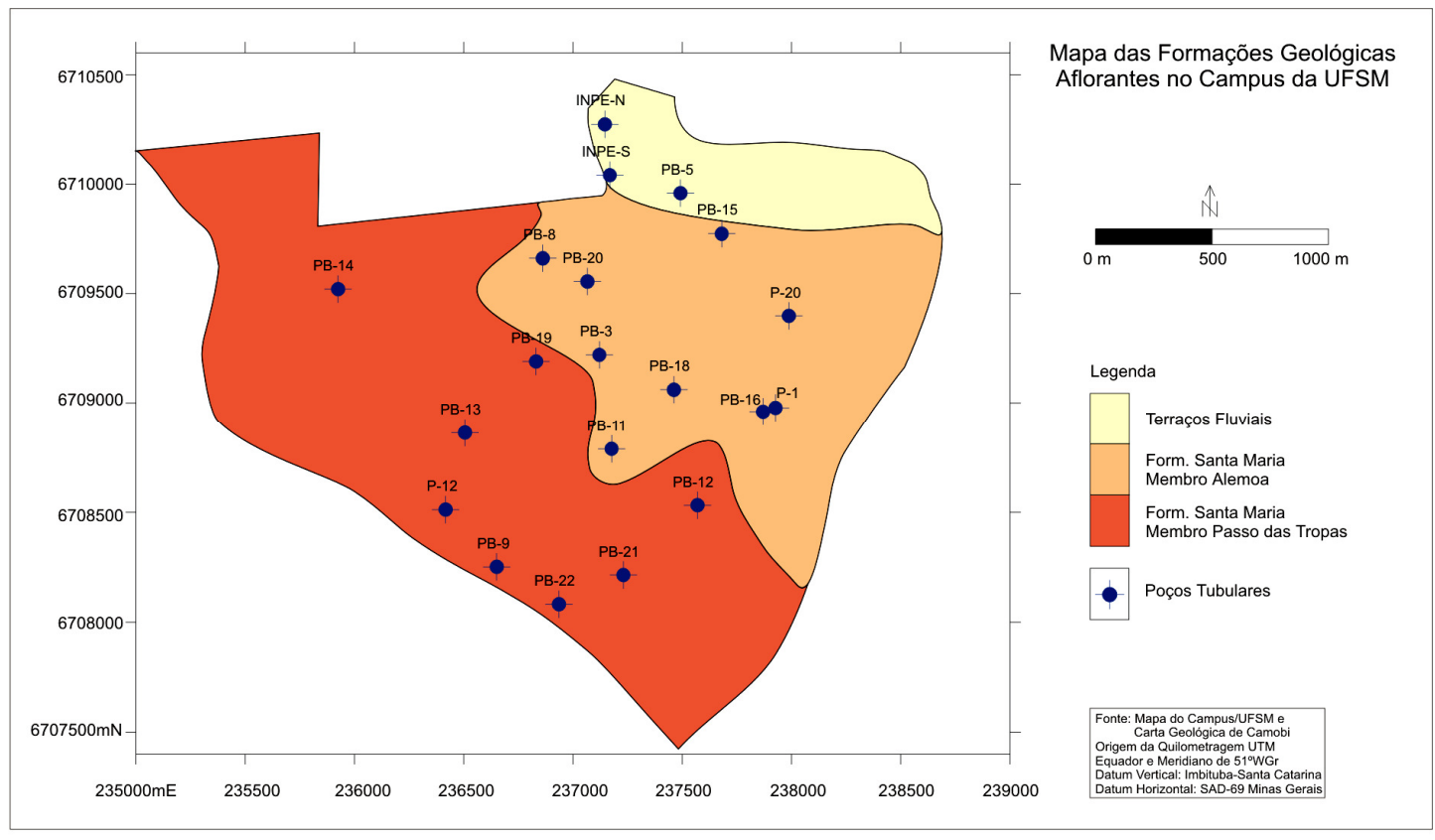

Figura 3. Mapa das formações geológicas aflorantes (ZA) SAG no Campus da UFSM até 2004. 


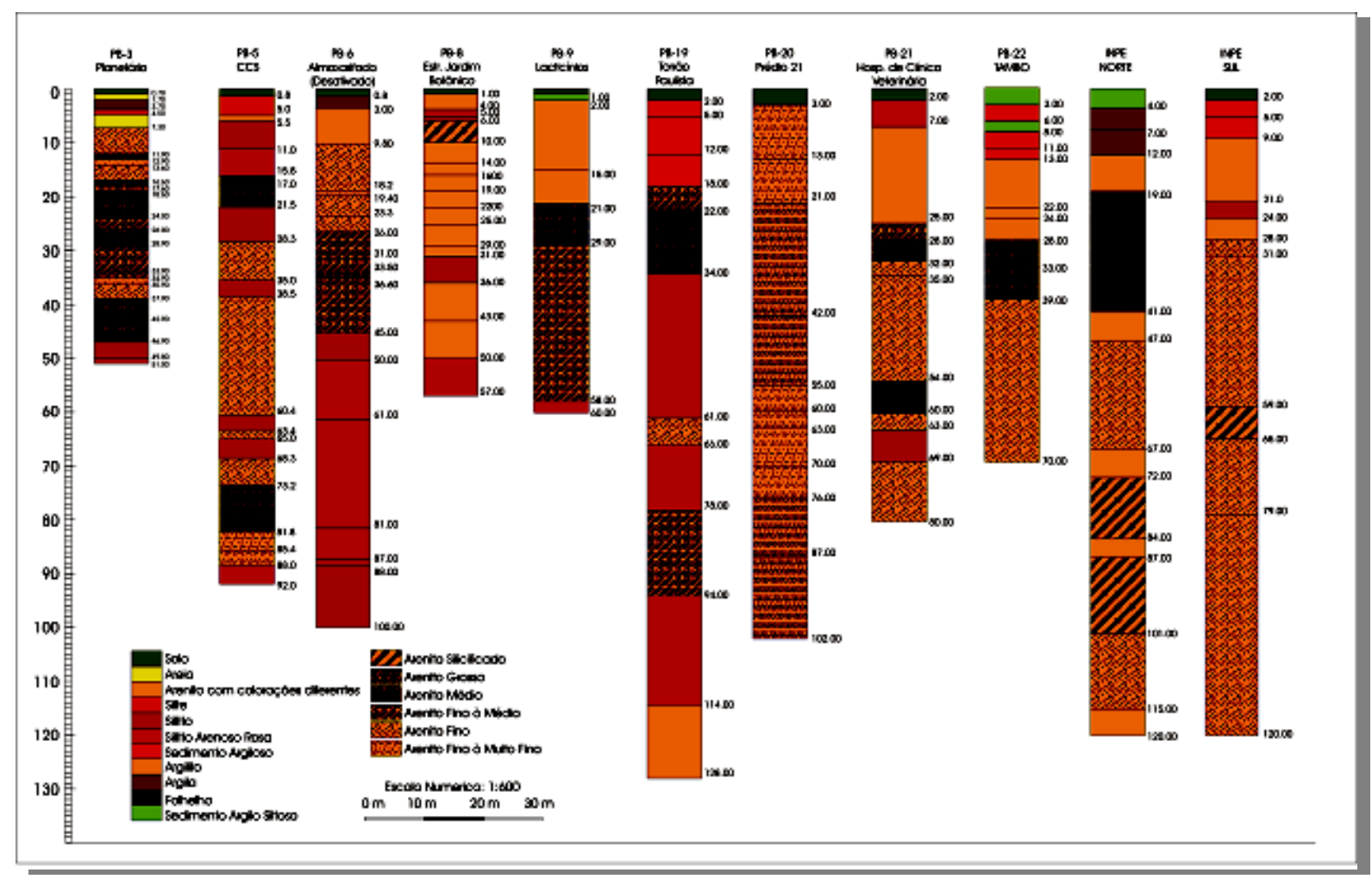

Figura 4. Seç̧ões transversais litológicas de alguns poços com bomba submersa (ZA) SAG.

A Figura 5 ilustra o mapa das redes de fluxo e sugere que na porção Norte ocorreu a menor carga hidráulica, atingindo cerca de $30 \mathrm{~m}$ sobre o Datum sugerindo a ocorrência de um baixo potenciométrico. No entanto a classe predominante estimada foi entre 75 e $85 \mathrm{~m}$, onde se situam nove poços. Outra classe expressiva foi entre 65 e $75 \mathrm{~m}$, onde se situram sete captações. Nota-se uma tendência geral de fluxo subterrâneo de direção Sudoeste para Nordeste onde ocorrem alguns cursos de água associados à Bacia Hidrográfica do Rio Vacacaí e Vacacaí-Mirim (G-70) SEMA (2004). 


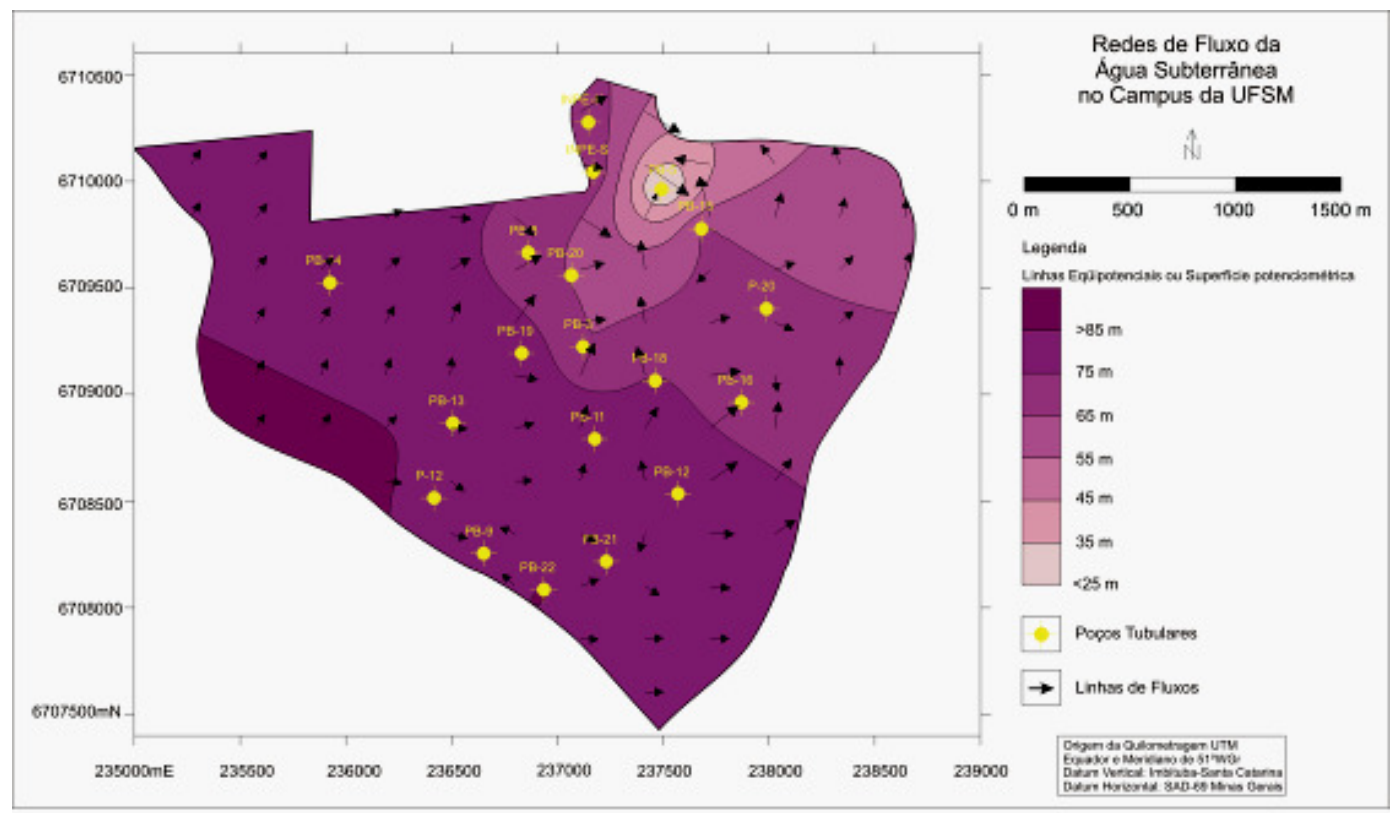

Figura 5. Redes de Fluxo (superfície potenciométrica e linhas de fluxos) da água subterrânea no Campus da UFSM

\section{CONCLUSÕES}

Notoriamente nas últimas décadas a utilização da água subterrânea para o consumo humano aumentou significativamente em relação às águas superficiais, porém existe uma crescente preocupação com relação aos padrões de qualidade da água consumida.

Assim, se obteve diferentes informações quanto às características construtivas das captações. Os poços mais antigos não possuíam registros disponíveis ou eventualmente estavam incompletos. Já os poços que foram perfurados recentemente, Figura 2, possuíam mais informações tendo em vista a preocupação em atender a legislação vigente e aos critérios de outorga dos recursos hídricos subterrâneos.

O banco de dados hidrogeológicos necessita ser atualizado periodicamente com novas informações tanto de quantidade quanto de qualidade. Os resultados estão sendo disponibilizados aos interessados na página da web da UFSM/LABHIDROGEO.

Analisando-se a condição de funcionamento dos poços observou-se que estes foram adequados as Normas Técnicas - ABNT, inclusive com perímetro mínimo de Proteção Figura 2.

Dentre os poços desativados, alguns destes estão servindo de pesquisas, dissertações e formação de recursos humanos e ainda registrando-se uma série histórica de níveis. Estes procedimentos buscam evitar a sobrexplotação de recursos hídricos subterrâneos e sua gestão racional.

Sugere-se a instalação de piezômetros ou poços de monitoramento monitorados dotados de registradores automáticos de nível de água.

A partir dos registros de flutuação níveis estáticos dos poços, estes puderam ser associados ao crescimento do consumo de água e/ou relativos às alterações climáticas. 
Evidenciou-se que elas alteram a capacidade de recarga do aquífero conforme observado no balanço hídrico de curta duração. Sugere que esta hipótese seja melhor investigada e confrontada com outros métodos.

Sugere-se a instalação de medidores de retiradas de água (hidrômetros) em todas as captações registrando dados continuamente e informando aos usuários para tomada de consciência.

A gestão dos recursos hídricos no Brasil ainda está voltada para as águas superficiais, mas como as águas subterrâneas são parte do Ciclo hidrológico sua interação deve ser investigada.

Cabe destacar que não são suficientes somente leis para a gestão ambiental, torna-se necessária a tomada de consciência e uma ampla participação dos usuários na proteção. Uma vez que este recurso é renovável. Portanto seu uso e preservação devem ser considerados, tanto para a atual como para as futuras gerações.

Agradecimentos a todos os que participam da gestão dos recursos hídricos subterrâneos do Campus da UFSM, LAQIA/CCNE, GEHRI, CPRM.

\section{REFERÊNCIAS}

ASSOCIAÇÃO BRASILEIRA DE NORMAS TÉCNICAS/ABNT. NBR 12244: Poço Tubular - Construção de poço para captação de água subterrânea: Rio de Janeiro, 2006. 10p.

.NBR 12212: Poço Tubular- Projeto de poço para captação de água subterrânea. Rio de Janeiro, 2006. 10p.

.NBR Poço Tubular: Construção e execução de fossas sépticas. Rio de Janeiro, 1993. 23p.

BRASIL CONAMA - Consel ho Nacional do Meio Ambiente. Resolução № 20 de 18 de junho de 1986. Estabelece a classificação das águas do Território Nacional e disciplina o enquadramento dos cursos de águas nas classes. Brasília, 1986.

BRASIL, MINISTÉRIO DA SAÚDE. Portaria MS N²914, de 12/12/2011. Brasília, 2011. Dispõe sobre os procedimentos de controle e de vigilância da qualidade da água para consumo humano e seu padrão de potabilidade.

COMPANHIA DE PESQUISA E RECURSOS MINERAIS/CPRM. Mapa hidrogeológico da folha SH.22-V-C-IV (MI2965).

Escala 1:100.000, 1994.

COMPANHIA DE PESQUISA E RECURSOS MINERAIS/CPRM, Relatório do Poço PB-20/UFSM. Superintendência Regional de Porto Alegre. Diretoria de Recursos Minerais. Departamento de Exploração, 1996. 17p.

COMPANHIA DE PESQUISA E RECURSOS MINERAIS/CPRM. Disponível em: http://www.cprm.gov.br/RIMAS. Visitada em 11/12/2011.

CUSTÓDIO, E. e LLAMAS, M. R. Hidrología subterránea. 2a ed. Barcelona: Omega, 2v. 1983.

D'AVILA, R. F. Ensaio metodológico de avaliação de impacto antrópico da Bacia Hidrográfica da UFSM/RS. 2009, 173 f. Dissertação (Mestrado em Engenharia Civil). Universidade Federal de Santa Maria. Centro de Tecnologia, PPGEC, RS. DREVER, J. I. The geochemistry of natural waters: Surface and Groundwater Environments. Third Edition, Prentice Hall, Inc. 1997, 436p.

ESTADO DO RIO GRANDE DO SUL, DECRETO № 42.047. De 26 de Dezembro de 2002. Regulamenta disposições da Lei № 10.350, de 30 de dezembro de 1994, com alterações, relativas ao gerenciamento e à conservação das águas subterrâneas e dos aquíferos no Estado do Rio Grande do Sul. Disponível em: http//: www.sema.rs.gov.br/legis. Acesso em 25 de janeiro 2009.

FEITOSA, A. C. F.; MANOEL FIHO, J.; FEITOSA, E. C.; DEMETRIO, K; G; A. HIDROGEOLOGIA - Conceitos e Aplicações; CPRM - Serviço Geológico do Brasil, LABHID, Cap. 5, 3 a ed. revisada e ampliada- Rio de Janeiro. 2008, 812p. FREITAS, M. A.; MACHADO, J. L. F.; VIERO, A. C.; TRAININI, D. R.; GERMANO, A. de O.; GLUGLIOTTA, A. P.; CAYE, B. R.; PIMENTEL, G. de B.; MARQUES, J. L.; GOFFERMANN, M.; SILVA, P. R.R. da. Mapa Hidrogeológico do Rio Grande do Sul: um avanço no conhecimento das águas subterrâneas no Estado. In.: Anais. XIII Congresso Brasileiro de Águas Subterrâneas. Cuiabá, 19 a 22 de out. de 2004.

FOSTER, S.; HIRATA, R.; GOMES, D.; D'ELIA, M.; PARIS, M.. Protección de la Calidad del Agua Subterránea: guía para empresas de agua, autoridades municipales y agencias ambientales. Banco Mudial. Washington, D.C.: Mundi-Prensa Libros, S.A., 2003.

GASPARETTO et al. (1990) Mapa Geológico da Folha de Camobi. UFSM. Esc. 1:50.000. 
GIARDIN, A. e FACCIN, U. Complexidade hidroestratigráfica e estrutural do Sistema Aquífero Guarani: abordagem metodológica aplicada ao exemplo da área de Santa Maria-RS, Brasil. Revista Águas Subterrâneas. №18 ABAS. 01/2004 p.39-53 HAUSMAN, A. Províncias Hidrogeológicas do Estado do Rio Grande do Sul. Estudos tecnológicos, Universidade do Vale do Rio dos Sinos, São Leopoldo-RS, 1995, 125p.

HIRATA, R.; BASTOS, C.; ROCHA, G. Mapeamento da vulnerabilidade e risco de poluição das águas subterrâneas no Estado de São Paulo. Secretaria do Estado de São Paulo. São Paulo: Instituto Geológico, CETESB, DAEE, 1997. 2 volumes, 128p.

LANDIM, P. M. B., MONTEIRO, R.C. CORSI, A. C. Introdução à confecção de mapas pelo software SURFER. Geomatemática. Texto Didático 8, DGA, IGCE, UNESP/Rio Claro, 20pp., 2002. Disponível em <http:www.rc.unesp.br/igce/aplicada/textodi.html> Acesso em 11/05/2008.

LANDIM, P. M. B. e STURARO, J. R. Krigagem indicativa aplicada à elaboração de mapas probabilísticos de riscos. DGA, IGCE, UNESP/Rio Claro, Texto didático 06, 19pp., 2002. Disponível em <http:www.rc.unesp.br/igce/aplicada/textodi.html> Acesso em 11/05/2008.

MACIEL FILHO, C. L. Carta Geotécnica de Santa Maria, escala 1: 25.000, Santa Maria., 1988.

. Mapa da Universidade Federal de Santa Maria, em escala 1:7500, Projeto Bacia Escola. Santa Maria, 2000. LOBLER, C. A.; BORTOLOTTO, R. W.; TOSCANI, R. R.; SILVÉRIO DA SILVA, J. L. Avaliação dos Níveis dos Poços de Abastecimento da UFSM. In: Jornada Acadêmica Integrada, Santa Maria. 2010. Anais 25 JAI.

LOBLER, C. A.; TOSCANI, R. R.; SILVÉRIO DA SILVA, J. L. MONITORAMENTO DOS POÇOS TUBULARES DO CAMPUS DA UFSM. In: Jornada Acadêmica Integrada - JAI, 2011, Santa Maria. 26 Salão de Iniciação Científica Ciências Exatas e da Terra, 2011. Anais $26 \mathrm{JAI}$.

MARION, F. A.; CAPOANE, V.; SILVÉRIO DA SILVA, J. L. Avaliação da qualidade da água subterrânea em poço do Campus da UFSM, Santa Maria, RS. Ciência e Natura, Revista do CCNE, Santa Maria, volume 29 (1): 97-109, 2007. MARION, F. A. Avaliação da vulnerabilidade das águas subterrâneas por geoprocessamento, no Campus da UFSM - RS, 2009. 94f. Dissertação (mestrado em Geomática) Universidade Federal de Santa Maria, Centro de Ciências Rurais, Programa de Pós-Graduação em Geomática, RS.

MOREIRA, C. M. D. Aspectos qualitativos da Água subterrânea no campus da UFSM, Santa Maria - RS. 2005, 138 f. Dissertação (Mestrado em Engenharia Civil) - Universidade Federal de Santa Maria, Centro de Tecnologia, PPGEC, RS. OAS/SAP/2009 Organization of American States/OAS/SAP. Guarani Aquifer strategic action program = Acuífero Guaraní programa estratégico de ación. Bilingual edition- Brazil, Argentina, Paraguay, Uruguay. January 2009.222 p. OSÓRIO, Q. da S.; DUTRA, D. de A.; ALVES, E. M.; CASSOL, R. Balanço hídrico climático entre o período de 2000 e 2001 para a Bacia Hidrográfica no Arroio Arenal, Santa Maria/RS In. V - Simpósio Brasileiro de Climatologia Geográfica "Mudanças Globais e Especificidades Climáticas Regionais e Locais: Avanços e Desafios da Climatologia Contemporânea"; Curitiba/PR. 04 a 06/12/2002.

PEREIRA, A. R.; ANGELOCCI, L. R; SENTELHAS, P. C. Agrometeorologia: fundamentos e aplicações práticas. Guaíba: Agropecuária, 2001. 478p.

SECRETARIA DO MEIO AMBIENTE do Estado do Rio Grande do Sul/SEMA. Mapa das Bacias hidrográficas do estado. Impresso, 2004.

RECHZIEGEL, T. Modelo Conceitual de Avaliação Ambiental Solo/Água para Remediação de Sítio Degradado.

Dissertação de Mestrado PPGEC/UFSM, em execução. Defesa agosto/2012.

SILVÉRIO DA SILVA, J. L., FLORES E. M. M., BERTAZZO,V. M., Estudo hidroquímico das Águas Subterrâneas da Região de Santa Maria, no RS. XXVII Congreso Internacional Ingenieria Sanitária y Ambiental, 2000, p.10.

SANTIAGO, M.R. e SILVÉRIO DA SILVA, J. L., Variabilidade na concentração de elementos químicos em poço único. Conferência Internacional. A gestão do SAG: um exemplo de cooperação. Disponível em http://www.cepas.net.br. Anais, impresso. p. 28.

SANTIAGO, M.R. Análise das ocorrências de Flúor em águas subterrâneas.

SILVÉRIO DA SILVA, J. L.; MENEGOTTO, E. e MEDEIROS, E. R. Avaliação preliminar dos Argilominerais das Folhas de Camobi e Santa Maria, RS. Ciência e Natura. v. 12, 1990, p. 127-132.

SILVÉRIO DA SILVA, J. L. 1997. Estudo dos processos de silicificação e calcificação em rochas sedimentares Mesozóicas do Estado do Rio Grande do Sul, Brasil, Curso de Pós-Graduação em Geociências, UFRGS, Tese de doutorado em Geociências. p. 156, XLVI pranchas e 107 figuras.

SILVÉRIO DA SILVA et al. Características morfológicas do Membro Alemoa, Formação Santa Maria, Rio Grande do Sul. In: Anais do VIII RSBCS, Reunião Sulbrasileira de Ciência do Solo, UFSM, 2010.

STRECK, E. V. et al. Solos do Rio Grande do Sul. EMATER/RS, 2eed. Rev. e Ampl., 2008. p. 222.

SURFER 8. User's Guide. Contouring and 3D Surface mapping for Scientists and Engineers. Golden Software, 2002. 640p. 